\section{Epidemiological surveillance of main vector borne arboviral diseases in Brazil: a brief review}

\author{
Vigilância epidemiológica das principais doenças arbovirais \\ transmitidas por vetores no Brasil: uma breve revisão
}

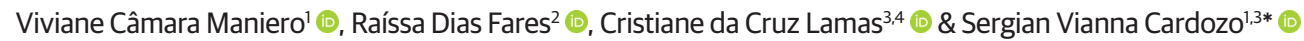 \\ 'Biologist, DSc. Programa de Pós-Graduação em Biomedicina Translacional, Universidade do Grande Rio (UNIGRANRIO), \\ Duque de Caxias, RJ, Brasil \\ 2Dentist. Departamento de Saúde, Faculdade de Odontologia, UNIGRANRIO, Duque de Caxias, RJ, Brasil \\ ${ }^{3}$ Veterinarian, DSc. Departamento de Saúde, Faculdade de Medicina, UNIGRANRIO, Duque de Caxias, RJ, Brasil \\ 4Physician, DSc. Instituto Nacional de Infectologia Evandro Chagas, Fundação Oswaldo Cruz, Rio de Janeiro, and Departamento \\ de Saúde, Faculdade de Medicina, UNIGRANRIO, Duque de Caxias, RJ, Brasil
}

\begin{abstract}
In recent years, there has been an increase in infections caused by arboviruses in tropical countries, resulting in 700,000 deaths yearly; this is now considered a worldwide public health problem. In Brazil, dengue, Zika, and chikungunya are the main circulating arboviruses, which can be transmitted by the same vectors (Aedes aegypti and Aedes albopictus). In addition, more than $80 \%$ of the world's population lives in areas that are at a risk of having at least one of the main vector-borne diseases, as vector control remains neglected. To optimize interventions, it is necessary to make greater strategic investments, i.e., to improve entomological surveillance and coordination within and between sectors as well as to strengthen monitoring systems. For implementation, the anatomy, physiology, and habits of the vectors must be known in order to adopt correct measures for the control of these vectors. Thus, several methods are used according to climatic conditions, regions, and rainfall, as these directly influence the vector cycle. Finally, the use of techniques applied in molecular surveillance, such as xenomonitoring, can help to control vectors, thus preventing new outbreaks of arboviruses.
\end{abstract}

Keywords: Aedes aegypti, Aedes albopictus, arboviruses, and vector control.

\section{Resumo}

Nosúltimos anos, tem ocorrido um aumento de arboviroses em países tropicais, acarretando 700.000 mortes por ano, sendo considerado um problema de saúde pública mundial. No Brasil a dengue, Zikae Chikungunya são as principais arboviroses em circulação, que podem ser transmitidas pelos mesmos vetores (Aedes aegypti eAedes albopictus). Além disso, mais de 80\% da população mundial, viveemáreas de risco de pelo menos uma das principais doenças transmitidas por vetores, apesar disso, o controle de vetores permanece negligenciado. Para otimizar o fornecimento de intervenções, se torna necessário realizar maiores investimentos estratégicos, ou seja, melhorar a vigilância entomológica e a coordenação dentro e entre os setores, além de fortalecer sistemas de monitoramento. Para tal deve se conhecer a anatomia, fisiologia e os hábitos dos vetores, para se adotar as medidas corretas para o controle desses vetores. Dessa forma, são utilizados diversos métodos de acordo com as condições climáticas, região e pluviosidade, pois essas influenciam diretamente no ciclo do vetor. Por fim, o uso de técnicas aplicadas na vigilância molecular, como o xenomonitoramento, pode auxiliar no controle de vetores, prevendo novos surtos de arboviroses.

Palavras-chave: Aedes aegypti, Aedes albopictus, arboviroses e controle de vetores.

\section{Introduction}

Arboviruses are a group of viruses transmitted by vectors (viruses transmitted by arthropods). The World Health Organization (WHO) recognized these diseases as a global public health problem. Indeed, their territorial dispersion is increasing, and the required prevention and control measures are becoming increasingly complex (World Health Organization, 2017).

\section{B] M \\ Brazilian Journal of Veterinary Medicine}

p-ISSN 0100-2430

How to cite: Maniero, V. C., Fares, R. D., Lamas, C. C., \& Cardozo, S. V. (2021). Epidemiological surveillance of main vector borne arboviral diseases in Brazil: a brief review. Brazilian Journal of Veterinary Medicine, 43, e001420. [[Q2: Q2]] https://doi.org/10.29374/2527-2179.bjvm001420

Received September 22, 2020. Accepted November 17, 2020.

\section{*Correspondence}

Sergian Vianna Cardozo

Programa de Pós-graduação em Biomedicina Translacional, Departamento de Saúde, Universidade do Grande Rio - UNIGRANRIO Rua Professor José de Souza Herdy, 1160, Jardim Vinte e Cinco de Agosto CEP 25071-202 - Duque de Caxias (RJ), Brasil E-mail:sergianvc@unigranrio.edu.br
Copyright Maniero et al. This is an Open Access article distributed under the terms of the Creative Commons Attribution Non-Commercial License which permits unrestricted non-commercial use, distribution, and reproduction in any medium provided the original work is properly cited. 
The interest in arboviruses is not only related to their transmission through arthropods. The main characteristic of arboviruses is that their replicative cycle occurs in insects. Consequently, in order to classify an arthropod as a carrier of an arbovirus, it must have the capacity to infect vertebrates and invertebrates. Furthermore, induced viremia in the vertebrate host must last long enough to allow infection of the invertebrate vector. This infection must initiate a productive and persistent infection of the invertebrate salivary gland in order to multiply virus particles for infection of other vertebrate hosts (Casseb et al., 2013). Thus, arboviruses have varied hosts, either vertebrates or invertebrates, causing diseases in humans and other animals, and are classified into five viral families: Bunyaviridae, Togaviridae, Flaviviridae, Reoviridae, and Rhabdoviridae (Lopes et al., 2014).

In Brazil, the Aedes vector has been widely disseminated since the second half of the twentieth century. Since then, the vector itself has been adapting to new arboviruses, climatic conditions, and disordered urban growth, and the use of insecticides. Thus, the main arboviruses that have a wide global geographical distribution are related to emerging and reemerging diseases that are mandatory to report (World Health Organization, 2020). They are Dengue (DEN), Zika (ZIK), and Yellow Fever (YF) belonging to the Flaviviridae family, and chikungunya (CHIK) related to the Togaviridae family.

DENis themostprevalent arbovirusinfection transmitted to humans viamosquitoes. It is present in several countries with tropical and subtropical regions, mainly in urban and semi-urban environments. In Brazil, three regions always present an expressive number of cases, Midwest, South, and Southeast (Brasil, 2020). In 2014 and 2015 in Brazil, CHIK and ZIK initially emerged in the North Region to disperse in different regions such as the Southeast, Northeast, and Midwest and finally the South. So far, they represent the lowest number of suspected cases of these arboviruses (Brasil, 2015a, 2020).

Currently, different control measures are used to control the vector. For instance, the Larval Index Rapid Assay is used to estimate the Property Infestation Index (IIP) and the Breteau Index (IB). These indices aim to identify the number of properties containing mosquito larvae that cause arboviruses. The purpose of this review was to report the biological characteristics of the vectors (Aedes aegyptiand Aedes albopictus) of the main circulating arboviruses in Brazil (DEN, CHIK, and ZIK), emphasizing the transmission and dispersion aspects, in addition to the prevention and control measures studied currently for these vectors.

\section{Vector competence}

For a vector to become competent, capable of acquiring, maintaining, and transmitting arboviruses, it is necessary to have co-adaptation between viruses and vector. The virus, in turn, needs to overcome intrinsic (genetic) factors and mechanisms. These are considered innate pathways related to the mosquito's immunity and tissue barriers. They are present in the following locations: midgut, midgut escape, salivary gland, and escape from the salivary gland. With this, it manages to establish itself through a process of infection and viral spread (Okuda et al., 2002). The contact between the arbovirus and the vector occurs through the ingestion of the virus during a blood meal (Okuda et al., 2002). The blood then reaches the midgut, where receptor recognition occurs, followed by endocytosis. If the vector-virus combination is not compatible, the midgut epithelium cannot be infected by the virus, and is excreted by the mosquito (Okuda et al., 2002).

If there is compatibility between the vector and the virus, the infection will occur within 5-7 days (Salazar et al., 2007). Infection patterns of the midgut epithelial cells vary according to the virus-vector species combination (Zhang et al., 2010).

With the spread of the virus in the midgut, other parts/cells, such as hemocytes, adipose bodies, neural tissue and muscle tissue, and the salivary glands, are further infected. In order to infect the salivary glands, the infection of hemocytes and adipose bodies is essential. However, the success of infection in the salivary glands and escape from the salivary glands will depend on the interaction of the arboviral strain with the mosquito species (Chouin-Carneiro et al., 2016; Pierro et al., 2007).

The arbovirus infection of the salivary glands is similar to that of the midgut (Paulsons et al.,1992). The period between the ingestion of infected blood and the spread of viral particles in the salivary glands is known as the 10-14-day incubation period and is influenced by the ambient temperature (Carrington et al., 2013). 
Finally, when the mosquito's salivary glands are infected, the virus is transmitted through the saliva, confirming vector competence (Carrington et al., 2013). This vector competence appears to be determined by genotype-genotype interactions (Vega-Rúa et al., 2014). Therefore, the vector competence of mosquito populations is a key parameter for assessing the risk of transmission of DEN and CHIK.

Subsequently, successful transmission appears to depend on the specific combination of mosquito and viral genetic characteristics (Volk et al., 2010).

\section{Vector dispersion}

Since the 1950s, Brazil has experienced an increasingly accelerated urbanization process, mainly due to the intensity of industrialization. This urbanization impacted by economic development had both positive and negative effects on the population's health. Indeed, inadequate planning of new housing areas over the years has favored the emergence of potential vectors generating arboviruses in the national population (De Melo-Santos et al., 2009). During the mid-70s, South America, in addition to housing a substantial portion of the world population, was also characterized as a region conducive to potential vector breeding sites, such as Ae. aegypti. Owing to urbanization, the incidence of DEN in the country has been a public health problem till today (Horta et al., 2013). Rapid urbanization in Latin America and Asia favored the dispersion of the main vectors of DEN, CHIK, and ZIK. Another factor that also played an important role in this process was the increase in the number of travelers to North America, Australia, and Japan (Schwartz et al., 2008; Streit et al., 2011).

Aedes albopictus has dispersed from the forests of Southeast Asia, over the past three decades to several countries in the Americas, Central Africa, Europe, the Pacific, and the Indian Ocean Islands, and the Australian continent. This rapid dispersion was due to the ease of transportation of eggs and their ability to diapause (Ramasamy et al., 2011).

Aedes albopictus was first recorded in 1986 in the state of Rio de Janeiro. Later that year, it was recorded in São Paulo and Minas Gerais as well. The following year, it was recorded in Espírito Santo. Within one year, it spread to all states in the Southeast region. Furthermore, there is a continuous growth and disordered dispersion of this vector throughout the country, which has been adapting more and better to urbanized regions (Castro et al., 2004; Fernández et al., 2004).

A major territorial infestation of Ae aegypti in the Caribbean islands in the late 1970s culminated in the increase of CHIK cases. Three factors were responsible for this: 1) the epidemic occurred in the rainy season, increasing the vector population; 2) high levels of commercial transport in the region, as well as a vast transitory population temporarily employed in these areas; and 3) a decrease in the implementation of control measures that led to an increase in vector infestation (Fernández-Salas et al., 2015).

\section{Transmission of arboviruses}

Arboviruses are maintained in a transmission cycle between vertebrate hosts and arthropods (Gubler, 2001). Arthropod hosts, generally referred to as vectors, are mosquitoes that obtain blood meals. Rather than a simple alternation within a single host-vector pair, arbovirus transmission often occurs through highly complex transmission networks that include multiple hosts and vectors (Diaz et al., 2013). Humans, in particular, are not necessarily the center of the transmission network and may only be accidental hosts (e.g., West Nile virus). Climatic conditions interfere in the reproductive activity of mosquito vectors throughout the year. In the dry season in tropical areas or the cold season in temperate regions, there is a decrease in the density of these adult mosquitoes, interrupting continuous transmission from hosts to vectors (Leake, 1984; Rubel \& Kottek, 2010).

Thus, the survival of mosquitoes during the dry and cold seasons encompasses different physiological and/or behavioral mechanisms. These interfere with the transmission of the virus in a different way. Horizontal transmission encompasses all other modes of non-parental transmission, including sexual transmission and vector transmission (Rubel \& Kottek, 2010). Transovarial or vertical transmission refers to the transmission of a pathogen through the infected female, who can transmit the virus throughout her life and to her offspring, once the infection reaches the germinal tissues. The combination of the two modes of transmission allows pathogens 
to persist under conditions that would otherwise lead to their extinction (Rubel \& Kottek, 2010). Demographic and epidemiological changes in host populations lead to different opportunities for transmission in one way or another (Rubel \& Kottek, 2010).

Although DEN is mainly transmitted by the bite of females infected by human blood (horizontal transmission), both vertical (in which the infected mosquito is able to transmit the virus to its progeny) and venereal transmission (when an infected male transmits the virus to the female during copulation) has been suggested as an important mechanism for maintaining the circulation of arboviruses in vector populations (Ferreira-de-Lima \& Lima-Camara, 2018; Honório et al., 2019). It appears that infected male Aedes may play a role in maintaining DENV in the wild (Choochote et al., 2001; Dos Reis et al., 2019; Sánchez-Vargas et al., 2018). When the density of susceptible hosts is low, transovarial transmission becomes an essential link in the chain of transmission or re-introduction of the virus, which may also occur due to the existence of reservoir hosts (Lipsitch et al., 1996; Reeves, 2004).

The ZIK has two cycles: a wild one involving non-human primates and mosquitoes that inhabit the forest, and another urban/suburban one involving humans and Ae. aegypti and, to a lesser extent Ae. albopictus. Three other arboviruses transmitted to humans can share these cycles (DEN, CHIK, and YF) (Monath, 2001; Musso \& Gubler, 2016; Petersen et al., 2016; Vasilakis \& Weaver, 2008; Weaver \& Reisen, 2010). ZIK can be transmitted through sexual, perinatal, and transfusion routes (World Health Organization, 2017).

Non-human primates have generally been considered the main host reservoirs for the wild cycle of DEN, ZIK, CHIK, and YF transmission. However, there is little evidence to support this theory. Furthermore, researchers have repeatedly warned that other animal species may play a role in the transmission dynamics of these viruses (Chevillon et al., 2008; Hanley et al., 2013; Hayes, 2009). The wild ancestors of the YF, CHIK, and ZIK cycles reside in Africa, while the DEN ancestral cycle resides in Southeast Asia with subsequent transport to West Africa and enzootic establishment (Wang et al., 2000).

In 2018, the wild transmission of ZIK in Brazil was reported in a study that experimentally examined two species of neotropical primates from the new world, which can serve as a reservoir host (Terzian et al., 2018; Vanchiere et al., 2018). In addition, a study with ZIK in marmosets showed that the animals had the characteristics of ZIK infection in humans. In this case, male marmosets did not show signs of clinical disease even with detected viremia (Chiu et al., 2017).

The same findings were observed in pregnant female marmosets as previously observed in humans, (Driggers et al., 2016; Terzian et al., 2018) demonstrating that placental viral replication occurs (Seferovic et al., 2018). DEN, in contrast, has not established a cycle of wild transmission in the Americas despite the spread by the circulation of the virus through the human-endemic cycle (Hanley et al., 2013). Currently, the majority of human infections due to the circulation of DEN occur exclusively in domestic and peridomiciliar environments throughout the tropics, where humans serve as the only amplification host. In this human cycle, Ae. aegypti is the main vector that transmits DEN while other Aedes spp., such as Ae. albopictus and Ae. polynesiensis, serve as secondary vectors (Chen \& Vasilakis, 2011).

In 2015 and 2016, the distribution of CHIK cases occurred in places close to the interior and forested areas. It resulted in an overlap with the YF's wild transmission cycle (Pan American Health Organization, 2016). Thus, it is likely that Ae. aegypti obtained a blood meal from infected primates in neighboring forests or its surroundings, and completed the urban cycle, where CHIK was transmitted to humans. These mosquitoes are competent and can initiate a wild cycle of CHIK as occurring in YF demonstrated by Lourenço-deOliveira \& Failloux (2017). The cycle of wild transmission in the New World would have immediate consequences on public health since it is difficult to control CHIK circulation (Lourenço-de-Oliveira \& Failloux, 2017).

\section{Control and prevention}

Considering there is still no vaccine or an effective drug available against these arboviruses, the recommendations by the Ministry of Health are mainly restricted to actions to combat household vectors. These include eliminating possible breeding sites and using clothes that minimize skin exposure during the day (when mosquitoes are most active), which provides 
some protection from bites, and should be adopted, especially during outbreaks. Repellents and insecticides must be used, following the manufacturer's instructions. Mosquito nets provide better protection, especially for those who sleep during the day (babies, bedridden people, and night workers) (Brasil, 2015b).

In Brazil, most Aedes surveillance programs are based on the traditional collection of home larvae by community agents, agents to combat endemic diseases, and finally with the help of the population. Subsequently, based on the indices, interventions for vector control are carried out. These can be chemical, biological, or mechanical based (Codeço et al., 2015; Gomes et al., 2008; Lagrotta et al., 2008). Despite these strategies, it has been shown that arbovirus prevention and control programs in Brazil are ineffective in combating these diseases. This is possibly due to difficult access to places where mosquito-breeding sites are present. These breeding sites are areas with urban violence due to dominance exercised by drug trafficking or militiamen, areas without basic sanitation located in hillside regions, among others. In this context, it is already known that adult mosquitoes constitute the stage directly involved in the transmission of viruses. Thus, their use in molecular surveillance strategies in routine prevention programs could become an important tool for monitoring the circulation of arboviruses in specific areas (Gu et al., 2008; Macedo et al., 2013; Thenmozhi et al., 2005).

Therefore, there is a need to develop new strategies as alternatives for the prevention and control of these arboviruses, mainly concerning combating vector insects (Capurro et al., 2001; Olson et al., 1996; Thavara et al., 2014).

\section{Rapid Index Survey for Aedes (LIRA)}

WHO and PAHO have encouraged the adoption of simplified sampling methods to facilitate data collection by health services that carry out entomo-epidemiological surveys (Brasil, 2013). From this and other needs arising from DEN epidemics, the National Dengue Control Program (PNCD) emerged in 2002. This program included Epidemiological Surveillance through a methodology capable of producing data in a short period. Within this program, larval indices are mostly used. Infestation rates based on the immature phase of the vector are used frequently. However, there are others, which use information related to eggs and adults as a basis (Brasil, 2013). There are many indices based on the immature phase (larvae and pupae). Additionally, as with any other method, it has advantages and disadvantages. Nevertheless, they are still the most preferred due to the quick and easy use (Gomes, 1998).

LIRA for Ae. aegypti and Ae. albopictus is performed quickly and safely, using the IIP and the IB as indicators. These indices are defined as tools for the evaluation of control measures, including data related to objects, making it possible to direct actions aimed at vector control (Brasil, 2013). The IIP, IB, and the objects are calculated for each stratum and the inspection of the properties of each block, to collect larvae and/or pupae, where $20 \%$ of the total of properties present in the studied district are visited, according to the National Guidelines for the Prevention and Control of Dengue Epidemics (Brasil, 2009).

\section{Health surveillance monitoring system and geo referencing}

The global DEN surveillance systems currently available include Dengue Net, the WHO central data management system for global epidemiological and virological surveillance (World Health Organization, 2012), and Dengue Map (Center for Disease Control, 2012), developed by the Center for Disease Control (CDC) in collaboration with Health Map. It uses the Geographic Information System (GIS) technology to monitor the transmission of DEN worldwide.

GIS technology, based on the prevalence of possible mosquito breeding sites and epidemiological data, has been used to assess the distribution and dynamics of mosquito populations or the risk of DEN in human populations (Brasil, 2015a; Hernández-Ávila et al., 2013; Kusnanto \& Sunartono, 2011; Zambrano et al., 2017). However, to our knowledge, there are currently no comprehensive national electronic surveillance systems with the level of geographical dissociation that show more detailed geographical areas, separated from each other. The ability of web-based GIS applications to facilitate time registration, integration, and analysis, can increase the capacity of national DEN surveillance programs and greatly assist in their prevention and control (Duncombe et al., 2012). 
When GIS is associated with the web and with national coverage for DEN control, it acts as a method of data collection and maintaining records at the local level. The GIS is also able to integrate and analyze information and aggregate temporal data of DEN cases relevant to each level of the health system (Hernández-Ávila et al., 2013). Moreover, the use of advanced techniques to control DEN is also implemented through private and public actions. The Strategic Monitoring of Epidemic Control (MECE) was developed through a partnership between the Fundação de Amparo a Pesquisa do Estado do Rio de Janeiro (FAPERJ) with the company AddTech $^{\circ}$ (Rio de Janeiro, Brazil).

The MECE is a mobile system for tracking and managing the actions of the public health departments that provide automation of the entire data collection system, reports of field actions, control of inputs, and general indices of the municipalities. In MECE, the results of laboratory analyses are inserted and the IIP and IB of the analyzed strata are calculated. All the data are collected and analyzed by the MECE system, generating real-time graphs and indices of the situation of infestation by vectors in the region.

\section{Molecular xenomonitoring}

In Brazil, molecular xenomonitoring is already implemented in surveillance for the control of lymphatic filariasis through the collection of mosquitoes. The aim is to detect the parasite's DNA by polymerase chain reaction (PCR) (Brasil, 2009).

Arbovirus monitoring using RT-PCR in larvae of Aedes spp. is performed sporadically by some surveys (Dos Reis et al., 2019; Farraudière et al., 2017; Gutiérrez-Bugallo et al., 2019; Medeiros et al., 2018). The RT-PCR has several advantages such as rapid detection, high sensitivity, and high specificity, and it can be applied in the virological surveillance of arboviruses (Gurukumar et al., 2009; LeparcGoffart et al., 2009), especially when negative results are obtained by other tests, such as virus isolation in cell cultures (Miagostovich et al., 1997). Our results corroborate with the high level of sensitivity of RT-PCR in pools containing a smaller number of Ae. aegypti obtained in other studies. In 154 pools (469 adults) of Ae. aegypti, 8 (5.2\%) were positive for one of the serotypes of DEN (Urdaneta et al., 2005) and with 47 pools of Aedes females (2005 Ae. aegypti and 212 Ae. albopictus) where they were positive 1/2005 for Ae. aegypti and 2/212 for Ae. albopictus for DENV (Martins et al., 2012).

A Brazilian study from a nearby area showed the presence of ZIK in surroundings, $615 \mathrm{immature}$ stages (larvae and pupae) were collected every two months from June 2015 to April 2016, 442 (72\%) of which were Ae. albopictus, and 173 (28\%) Ae. aegypti. The RT-qPCR was performed in all pools for the DEN, ZIK, and CHIK, and of the 64 pools analyzed, 3 were positive for ZIK, suggesting the occurrence of transovarial transmission of the species with 11.6\% (2/173) for Ae. aegypti and 2.3\% (1/442) for Ae. albopictus. The positive pools were from October 2015, containing 38 Ae. aegypti and December 2015, containing 33 larvae of Ae. albopictus and 3 larvae of Ae. aegypti (Maniero et al., 2019).

Due to the ZIK outbreak in Brazil, several cases of congenital syndromes mainly associated with microcephaly in newborns were reported with the detection of viral RNA in the amniotic fluid of the affected patients (Calvet et al., 2016). The threat posed by the ZIK has great implications for not only immediate public health but also family economy and social resources due to the persistent long-term sequelae of the congenital ZIK syndrome (Bogoch et al., 2016). Reliable and sensitive surveillance of these arboviruses, which includes a system for the detection of emerging pathogens, is of paramount importance in order to manage effectively future outbreaks.

\section{Chemical control - ultra low volume}

Currently, the most commonly used resource to combat vectors by health agents during home visits is the control performed with the use of chemicals that are neurotoxic, juvenile hormone analogs, and inhibitors of chitin synthesis to eliminate both larvae and adult insects (Braga \& Valle, 2007; World Health Organization, 1996). It is recommended to use these in a controlled and rational manner to ensure the safety of the population as well as the environment (Zara et al., 2016). Through new technologies, the use of adulticides and larvicides can be carried out by focal, peri-focal treatment, and even by aerospace spraying of insecticides in Ultra Low 
Volume (ULV) (Zara et al., 2016). The ULV consists of the fragmentation of a smaller amount of insecticide, generating aerosols, thus reaching all mosquitoes that are in the area (Brasil, 2009).

In addition, the costal ULV can be used in areas of difficult access as it does not need vehicles to transport it and because it is a non-selective method, i.e., other species end up being eliminated as well. The ideal is the use of portable equipment because its application is local, different from the application coupled to vehicles. Even so, its use is recommended only in epidemics (Brasil, 2009; World Health Organization, 1996). However, like microorganisms, vectors also end up developing resistance to the use of insecticides, as occurred with Ae. aegypti. Thus, the PNCD had to resort to the replacement of organochlorines with organophosphates (Malathion, Fenitrothion, and Temephos). These, in turn, are over time being replaced by pyrethroids (Cypermethrin and Deltamethrin) because of their effectiveness in fighting adult mosquitoes. Despite this, pyrethroids are costly and have an adverse environmental impact (Braga \& Valle 2007; Brasil, 2013; Guzman et al., 2010).

\section{Conclusions}

The climatic, geographical, and social characteristics currently established in Brazil combined with the biological characteristics of mosquito vectors of the genus Aedes spp., favor the multiplication and rapid dispersion of these vectors. This leads to a wide dissemination of arboviruses such as DEN, ZIK, CHIK, and YF providing the co-circulation of these arboviruses and others if they have compatible climatic and geographical conditions. Several technologies using different mechanisms of action, such as selective monitoring of infestation, social measures, dispersion of insecticides, biological control agents, and techniques for population control of mosquitoes, have been developed to control these vectors. We can use these technologies together. Molecular xenomonitoring, although still expensive, appears as a good alternative for identifying and predicting arboviruses in regions where their impact may congest the Unified Health System. The technologies under development demand an evaluation of the effectiveness, feasibility, and costs of implementation as complementary strategies to the actions already recommended by the PNCD.

Public policies for the prevention and control of vectors combined with the development of vaccines capable of preventing the infection in the population against these diseases may be the solution for the control and reduction of cases of arboviruses in Brazil and worldwide.

\section{Acknowledgements}

We would like to say thank to Conselho Nacional de Desenvolvimento Científico e Tecnológico - CNPq and Fundação de Amparo à Pesquisa no Estado do Rio de Janeiro - FAPERJ, to support this research. The funders had no role in the study design, data collection and analysis, decision to publish, or preparation of the manuscript.

\section{Ethics statement}

Not applicable.

\section{Financial support}

VCM, CCL - received a scholarship from Fundação de Amparo a Pesquisa no Estado do Rio de Janeiro - FAPERJ (grant n. E-26/201.772/2015), SVC - received a scholarship from Conselho Nacional de Desenvolvimento Científico e Tecnológico - CNPq (grant n. 114133/2016-6 and 124429/2017-3), RDF - None.

\section{Conflict of interests}

VCM, RDF, CCL and SVC - No conflict of interest.

\section{Authors' contributions}

VCM - Made substantial contributions to the conception and design of the work; taken part in writing the text / reviewed it critically for relevant intellectual contente. RDF - Made substantial contributions to the conception and design of the work; taken part in writing the text / reviewed 
it critically for relevant intellectual contente. CCL - Taken part in writing the text / reviewed it critically for relevant intellectual contente and approved the final version to be published. SVC Made substantial contributions to the conception and design of the work; taken part in writing the text / reviewed it critically for relevant intellectual contente; approved the final version to be published; agreed to be responsible for all the aspects of the work, assuring that all questions related to the precision or integrity of any part of the work were investigated and resolved suitably.

\section{Availability of complementary results}

\section{Not applicable}

The study was carried out at Universidade do Grande Rio - UNIGRANRIO, Duque de Caxias, RJ, Brasil.

\section{References}

Bogoch, I. I., Brady, O. J., Kraemer, M. U., German, M., Creatore, M. I., Kulkarni, M. A., Brownstein, J. S., Mekaru, S. R., Hay, S., Groot, E., Watts, A., \& Khan, K. (2016). Anticipating the international spread of Zika virus from Brazil. Lancet, 387(10016), 335-336. PMid:26777915.

Braga, I. A., \& Valle, D. (2007). Aedes aegypti: vigilância, monitoramento da resistência e alternativas de controle no Brasil. Epidemiologia e Serviços de Saúde : Revista do Sistema Unico de Saúde do Brasil, 16(4), 295-302.

Brasil. Ministério da Saúde. Secretaria de Vigilância em Saúde. (2009). Diretrizes Nacionais para a Prevenção e Controle de Epidemias de Dengue (Série A. Normas e Manuais Técnicos, 160 p.). Brasília: Ministério da Saúde.

Brasil. Ministério da Saúde. Secretaria de Vigilância em Saúde. Departamento de Vigilância das Doenças Transmissíveis. (2013). Levantamento Rápido de Índices para Aedes aegypti (LIRAa) para vigilância entomológica do Aedes aegypti no Brasil: metodologia para avaliação dos índices de Breteau e Predial e tipo de recipientes (84 p.). Brasília: Ministério da Saúde.

Brasil. (2015a).ANVISA Registra Primeira Vacina Contra Dengue no Brasil. http://portal.anvisa.gov.br/wps/content/ anvisa+ portal/anvisa/sala+de+imprensa/menu+noticias+anos/2015/anvisa+registra+primeira+vacina+con tra+dengue+no+brasil

Brasil. Ministério da Saúde. Secretaria de Vigilância em Saúde. (2015b). Monitoramento dos casos de dengue, febre de chikungunya e febre pelo vírus Zika até a Semana Epidemiológica 45. Boletim Epidemiológico, 46, 36.

Brasil. Ministério da Saúde. Secretaria de Vigilância em Saúde. (2020). Monitoramento dos casos de arboviroses urbanas transmitidas pelo Aedes aegypti (dengue, chikungunya e zika), semanas epidemiológicas 1 a 38, 2020. Boletim Epidemiológico, 51, 41, 1-39.

Calvet, G., Aguiar, R. S., Melo, A. S. O., Sampaio, S. A., de Filippis, I., Fabri, A., Araujo, E. S. M., de Sequeira, P. C., de Mendonça, M. C. L., de Oliveira, L., Tschoeke, D. A., Schrago, C. G., Thompson, F. L., Brasil, P., Dos Santos, F. B., Nogueira, R. M. R., Tanuri, A., \& de Filippis, A. M. B. (2016). Detection and sequencing of Zika virus from amniotic fluid of fetuses with microcephaly in Brazil: a case study. The Lancet. Infectious Diseases, 16(6), 653-660. PMid:26897108.

Capurro, M. L., Ribolla, P. E. M., de Bianchi, A. G., Marrelli, M. T., Magalhaes, M., Feitosa, F. M., Chinoca, J. P., \& Burini, B. (2001). Transgenics flies. Biotecnologia Ciencia \& Desenvolvimento, 18(22), 1-27.

Carrington, L. B., Armijos, M. V., Lambrechts, L., \& Scott, T. W. (2013). Fluctuations at a low mean temperature accelerate dengue virus transmission by Aedes aegypti. PLoS Neglected Tropical Diseases, 7(4), e2190. http:// dx.doi.org/10.1371/journal.pntd.0002190. PMid:23638208.

Casseb, A. D. R., Casseb, L. M. N., Silva, S. P. D., \& Vasconcelos, P. F. D. C. (2013). Arbovírus: importante zoonose na Amazônia Brasileira. Veterinária e Zootecnia, 20(3), 391-403.

Castro, M. G., Nogueira, R. M., Schatzmayr, H. G., Miagostovich, M. P., \& Lourenço-de-Oliveira R. (2004). Dengue virus detection by using reverse transcription-polymerase chain reaction in saliva and progeny of experimentally infected Aedes albopictus from Brazil. Memórias do Instituto Oswaldo Cruz, 99, 809-814. http:// dx.doi.org/10.1590/s0074-02762004000800005.

Center for Disease Control - CDC. (2012). Health Map. DengueNet. http://www.healthmap.org/dengue/

Chen, R., \& Vasilakis, N. (2011). Dengue-Quo tu et quo vadis? Viruses, 3(9), 1562-1608. http://dx.doi.org/10.3390/ v3091562. PMid:21994796.

Chevillon, C., Briant, L., Renaud, F., \& Devaux, C. (2008). The Chikungunya threat: an ecological and evolutionary perspective. Trends in Microbiology, 16(2), 80-88. http://dx.doi.org/10.1016/j.tim.2007.12.003. PMid:18191569.

Chiu, C. Y., Sánchez-San Martín, C., Bouquet, J., Li, T., Yagi, S., Tamhankar, M., Hodara, V. L., Parodi, L. M., Somasekar, S., Yu, G., Giavedoni, L. D., Tardif, S., \& Patterson, J. (2017). Experimental Zika Virus inoculation in a new world monkey model reproduces key features of the human infection. Scientific Reports, 7(1), 1-11. http://dx.doi. org/10.1038/s41598-017-17067-w. PMid:29215081. 
Choochote, W., Tippawangkosol, P., Jitpakdi, A., Sukontason, K. L., Pitasawat, B., Sukontason, K., \& Jariyapan, N. (2001). Polygamy:the possibly significant behavior of Aedes aegypti and Aedes albopictus in relation to the efficient transmission of dengue virus. The Southeast Asian Journal of Tropical Medicine and Public Health, 32(4), 745-748. PMid:12041548.

Chouin-Carneiro, T., Vega-Rua, A., Vazeille, M., Yebakima, A., Girod, R., Goindin, D., Dupont-Rouzeyrol, M., Lourenço-de-Oliveira, R., \& Failloux, A. B. (2016). Differential susceptibilities of Aedes aegypti and Aedes albopictus from the Americas to Zika virus. PLoS Neglected Tropical Diseases, 1O(3), e0004543. http://dx.doi. org/10.1371/journal.pntd.0004543. PMid:26938868.

Codeço, C. T., Lima, A. W. S., Araújo, S. C., Lima, J. B. P., Maciel-de-Freitas, R., Honório, N. A., Galardo, A. K. R., Braga, I. A., Coelho, G. E., \& Valle, D. (2015). Surveillance of Aedes aegypti: comparison of house index with four alternative traps. PLoS Neglected Tropical Diseases, 9(2), e0003475. http://dx.doi.org/10.1371/journal. pntd.0003475. PMid:25668559.

Diaz, L. A., Flores, F. S., Quaglia, A., \& Contigiani, M. S. (2013). Intertwined arbovirus transmission activity: reassessing the transmission cycle paradigm. Frontiers in Physiology, 3, 493. http://dx.doi.org/10.3389/ fphys.2012.00493. PMid:23335900.

Dos Reis, I. C., Gibson, G., Ayllón, T., de Medeiros Tavares, A., de Araújo, J. M. G., da Silva Monteiro, E., Rodrigues Aguiar, A., de Oliveira, J. V., de Paiva, A. A. P., Wana Bezerra Pereira, H., Dantas Monteiro, J., Sá Carvalho, M., Sabroza, P. C., \& Alves Honório, N., \& ARBOALVO Network. (2019). Entomo-virological surveillance strategy for dengue, Zika and chikungunya arboviruses in field-caught Aedes mosquitoes in an endemic urban area of the Northeast of Brazil. Acta Tropica, 197,105061. http://dx.doi.org/10.1016/j.actatropica.2019.105061. PMid:31194961.

Driggers, R. W., Ho, C.-Y., Korhonen, E. M., Kuivanen, S., Jääskeläinen, A. J., Smura, T., Rosenberg, A., Hill, D. A., DeBiasi, R. L., Vezina, G., Timofeev, J., Rodriguez, F. J., Levanov, L., Razak, J., Iyengar, P., Hennenfent, A., Kennedy, R., Lanciotti, R., du Plessis, A., \& Vapalahti, O. (2016). Zika Virus Infection with Prolonged Maternal Viremia and Fetal Brain Abnormalities. The New England Journal of Medicine, 374(22), 2142-2151. http://dx.doi. org/10.1056/NEJMoa1601824. PMid:27028667.

Duncombe, J., Clements, A., Hu, W., Weinstein, P., Ritchie, S., \& Espino, F. E. (2012). Geographical information systems for dengue surveillance. The American Journal of Tropical Medicine and Hygiene, 86(5), 753-755. http://dx.doi.org/10.4269/aitmh.2012.11-0650. PMid:22556070.

Farraudière, L., Sonor, F., Crico, S., Étienne, M., Mousson, L., Hamel, R., Missé, D., Failloux, A.-B., Simard, F., \& Yébakima, A. (2017). First detection of dengue and Chikungunya viroses in natural populations of Aedes aegypti in Martinique during 2013-2015 concomitant outbreak. Revista Panamericana de Salud Pública, 41, e63. http://dx.doi.org/10.26633/RPSP.2017.63. PMid:28902276.

Fernández, Z., Moncayo, A., Forattini, O. P., \& Weaver, S. C. (2004). Susceptibility of urban and rural populations of Aedes albopictus from Sao Paulo State, Brazil, to infection by dengue-1 and -2 viruses. Journal of Medical Entomology, 41(5), 961-964. http://dx.doi.org/10.1603/0022-2585-41.5.961. PMid:15535628.

Fernández-Salas, I., Danis-Lozano, R., Casas-Martínez, M., Ulloa, A., Bond, J. G., Marina, C. F., Lopez-Ordóñez, T., Elizondo-Quiroga, A., Torres-Monzón, J. A., \& Díaz-González, E. E. (2015). Historical inability to control Aedes aegypti as a main contributor of fast dispersal of chikungunya outbreaks in Latin America. Antiviral Research, 124, 30-42. http://dx.doi.org/10.1016/j.antiviral.2015.10.015. PMid:26518229.

Ferreira-de-Lima, V.H., \& Lima-Camara, T. N. (2018). Natural vertical transmission of dengue virus in Aedes aegypti and Aedes albopictus: a stematic review. Parasites \& Vectors, 11,77.http://dx.doi.org/10.1186/s13071-018-2643-9.

Gomes, A. D. C. (1998). Medidas dos níveis de infestação urbana para Aedes (Stegomyia) aegyptie Aedes (Stegomyia) albopictus em programa de vigilância entomológica. Informe Epidemiológico do SUS, 7(3), $49-57$.

Gomes, A. D. C., Silva, N. N. D., Bernal, R. T. I., \& Souza, A. D. (2008). Estimação da infestação predial por Aedes aegypti (Diptera:Culicidae) por meio da armadilha Adultrap. Epidemiologia e Serviços de Saúde : Revista do Sistema Unico de Saúde do Brasil, 17(4), 293-300.

Gu, W., Unnasch, T. R., Katholi, C. R., Lampman, R., \& Novak, R. J. (2008). Fundamental issues in mosquito surveillance for arboviral transmission. Transactions of the Royal Society of Tropical Medicine and Hygiene, 102(8), 817-822. http://dx.doi.org/10.1016/j.trstmh.2008.03.019. PMid:18466940.

Gubler, D. J. (2001). Human arbovirus infections worldwide. Annals of the New York Academy of Sciences, 951(1), 13-24. http://dx.doi.org/10.1111/j.1749-6632.2001.tb02681.x. PMid:11797771.

Gurukumar, K. R., Priyadarshini, D., Patil, J. A., Bhagat, A., Singh, A., Shah, P. S., \& Cecilia, D. (2009). Development of real time PCR for detection and quantitation of Dengue Viruses. Virology Journal, 23(6), 10. http://dx.doi. org/10.1186/1743-422X-6-10.

Gutiérrez-Bugallo, G., Piedra, L. A., Rodriguez, M., Bisset, J. A., Lourenço-de-Oliveira, R., Weaver, S. C., Vasilakis, N., \& Vega-Rúa, A. (2019). Vector-borne transmission and evolution of Zika virus. Nature Ecology \& Evolution, 3(4), 561-569. PMid:30886369.

Guzman, M. G., Halstead, S. B., Artsob, H., Buchy, P., Farrar, J., Gubler, D. J., Hunsperger, E., Kroeger, A., Margolis, H. S., Martínez, E., Nathan, M. B., Pelegrino, J. L., Simmons, C., Yoksan, S., \& Peeling, R. W. (2010). Dengue: a continuing global threat. Nature Reviews. Microbiology, 8(12, Suppl.), S7-S16. PMid:21079655. 
Hanley, K. A., Monath, T. P., Weaver, S. C., Rossi, S. L., Richman, R. L., \& Vasilakis, N. (2013). Fever versus fever: the role of host and vector susceptibility and interspecific competition in shaping the current and future distributions of the sylvatic cycles of dengue virus and yellow fever virus. Infection, Genetics and Evolution, 19, 292-311. http://dx.doi.org/10.1016/j.meegid.2013.03.008.

Hayes, E. B. (2009).Zika virus outside Africa. Emerging and Infectious Diseases, 15(9), 1347. http://dx.doi.org/10.3201/ eid1509.090442.

Hernández-Ávila, J. E., Rodríguez, M. H., Santos-Luna, R., Sánchez-Castañeda, V., Román-Pérez, S., Ríos-Salgado, V. H., \& Salas-Sarmiento, J. A. (2013). Nation-wide, web-based, geographic information system for the integrated surveillance and control of dengue fever in Mexico. PLoS One, 8(8), e70231. http://dx.doi.org/10.1371/journal. pone.0070231. PMid:23936394

Honório, N. A., Wiggins, K., Eastmond, B., Câmara, D. C. P., \& Alto, B. W. (2019). Experimental vertical transmission of chikungunya virus by brazilian and florida Aedes albopictus populations. Viruses, 11(4), 353. PMid:30999594.

Horta, M. A. P., Ferreira, A. P., de Oliveira, R. B., Wermelinger, E. D., de Oliveira Ker, F. T., Ferreira, A. C. N., \& Catita, C. M. S. (2013). Os efeitos do crescimento urbano sobre a dengue. Revista Brasileira em Promoção da Saúde, 26(4), 539-547.

Kusnanto, H. F. A., \& Sunartono, H. (2011). Web-based integrated DHF surveillance system in Sleman district Yogyakarta Indonesia. http://www.amic.org.sg/ ict/ external/ awards/ 0402A5- L48_Interim_Report1.pdf

Lagrotta, M. T. F., Silva, W., \& Souza-Santos, R. (2008). Identification of key areas for Aedes aegypti control through geoprocessing in Nova Iguaçu, Rio de Janeiro State, Brazil. Cadernos de Saúde Pública, 24, 70-80. http://dx.doi. org/10.1590/s0102-311x2008000100007.

Leake, C. J. (1984). Transovarial transmission of arboviruses by mosquitoes. In M. A. Mayo \& K. A. Herrop (Eds.), Vectors in Virus Biology (pp. 63-91). Academic Press

Leparc-Goffart, I., Baragatti, M., Temmam, S., Tuiskunen, A., Moureau, G., Charrel, R., \& de Lamballerie, X. (2009). Development and validation of real-time one-step reverse transcription-PCR for the detection and typing of dengue viruses. Journal of Clinical Virology, 45(1), 61-66. http://dx.doi.org/10.1016/j.jcv.2009.02.010. PMID: 19345140.

Lipsitch, M., Siller, S., \& Nowak, M. A. (1996). The evolution of virulence in pathogens with vertical and horizontal transmission. Evolution; International Journal of Organic Evolution, 50(5), 1729-1741. http://dx.doi. org/10.1111/j.1558-5646.1996.tb03560.x. PMid:28565576.

Lopes, N., Nozawa, C., \& Linhares, R. E. C. (2014). Características gerais e epidemiologia dos arbovírus emergentes no Brasil. Revista Pan-Amazônica de Saúde, 5(3), 55-64. http://dx.doi.org/10.5123/S2176-62232014000300007.

Lourenço-de-Oliveira, R., \& Failloux, A. B. (2017). High risk for chikungunya virus to initiate an enzootic sylvatic cycle in the tropical Americas. PLoS Neglected Tropical Diseases, 11(6), e0005698. http://dx.doi.org/10.1371/ journal.pntd.0005698. PMid:28662031.

Macedo, G. A., de Araújo, J. M., Schatzmayr, H. G., Costa, F. A., de Filippis, A. M., Santos, F. B., \& Nogueira, R. M. (2013). Virological surveillance for early warning of dengue epidemics in the State of Rio de Janeiro, Brazil. Transactions of the Royal Society of Tropical Medicine and Hygiene, 107(3), 141-146. http://dx.doi.org/10.1093/ trstmh/trs091. PMid:23322430.

Maniero, V. C., Rangel, P. S. C., Coelho, L. M. C., Silva, C. S. B., Aguiar, R. S., Lamas, C. C., \& Cardozo, S. V. (2019). Identification of Zika virus in immature phases of Aedes aegypti and Aedes albopictus: a surveillance strategy for outbreak anticipation. Brazilian Journal of Medical and Biological Research, 52(11), 1-8. http://dx.doi. org/10.1590/1414-431×20198339. PMid:31721902.

Martins, V. E., Alencar, C. H., Kamimura, M. T., de Carvalho Araújo, F. M., De Simone, S. G., Dutra, R. F., \& Guedes, M. I. (2012). Occurrence of natural vertical transmission of dengue-2 and dengue-3 viruses in Aedes aegypti and Aedes albopictus in Fortaleza, Ceara. PLoS One, 7(7), e41386. http://dx.doi.org/10.1371/journal.pone.0041386. PMid:22848479.

Medeiros, A. S., Costa, D., Branco, M., Sousa, D., Monteiro, J. D., Galvão, S., Azevedo, P., Fernandes, J. V., Jeronimo, S., \& Araújo, J. (2018). Dengue vírus in Aedes aegypti and Aedes albopictus in urban áreas in the state of Rio Grande do Norte, Brazil: Importance of virological and entomological surveillance. PLoS One, 13(3), e0194108. http://dx.doi.org/10.1371/journal.pone.0194108. PMid:29534105.

Melo-Santos, M. A. V., Araújo, A. P., Rios, E. M. M., \& Regis, L. (2009). Long lasting persistence of Bacillus thuringiensis serovar. israelensis larvicidal activity in Aedes aegypti (Diptera: Culicidae) breeding places is associated to bacteria recycling. Biological Control, 49(2), 186-191. http://dx.doi.org/10.1016/j.biocontrol.2009.01.011.

Miagostovich, M. P., Santos, F. B., Araújo, E. S. M., Dias, J., Schatzmayr, H. G., \& Nogueira, R. M. R. (1997). Diagnosis of dengue by using reverse transcriptase-polimerase chain reaction. Memorias do Instituto Oswaldo Cruz, 92(5), 595-600. http://dx.doi.org/10.1590/S0074-02761997000500006. PMid:9566225.

Monath, T. P. (2001). Yellow fever: an update. Lancet, 1, 11-20. http://dx.doi.org/10.1016/S1473-3099(01)00016-0.

Musso, D., \& Gubler, D. J. (2016). Zika virus. Clinical Microbiology Reviews, 29(3), 487-524. http://dx.doi.org/10.1128/ CMR.00072-15. PMid:27029595.

Okuda, K., de Souza Caroci, A., Ribolla, P. E., de Bianchi, A. G., \& Bijovsky, A. T. (2002). Functional morphology of adult female Culex quinquefasciatus midgut during blood digestion. Tissue and Cell, 34(3), 210-219. http:// dx.doi.org/10.1016/s0040-8166(02)00032-0. 
Olson, K. E., Higgs, S., Gaines, P. J., Powers, A. M., Davis, B. S., Kamrud, K. I., Carlson, J. O., Blair, C. D., \& Beaty, B. J. (1996). Genetically Engineered Resistance to Dengue-2 Virus Transmission in Mosquitoes. Science,272(5263), 884-886. http://dx.doi.org/10.1126/science.272.5263.884.

Pan American Health Organization - PAHO. (2016). Dengue: Guidelines for patient care in the región of the Americas. 2nd ed. PAHO.

Paulsons, S. L., Poirier, S. J., Grimstad, P. R., \& Craig Junior, G. B. (1992). Vector competence of Aedes hendersoni (Diptera: Culicidae) for La Crosse virus: lack of impaired function in virus-infected salivary glands and enhanced virus transmission by sporozoite-infected mosquitoes. Journal of Medical Entomology, 29(3), 483-488. PMid:1625297.

Petersen, L. R., Jamieson, D. J., Powers, A. M., \& Honein, M. A. (2016). Zika virus. The New England Journal of Medicine, 374(16), 1552-1563. http://dx.doi.org/10.1056/NEJMra1602113. PMid:27028561.

Pierro, D. J., Powers, E. L., \& Olson, K. E. (2007). Genetic determinants of Sindbis virus strain TR339 affecting midgut infection in the mosquito Aedes aegypti. Journal of General Virology, 88(5), 1545-1554. http://dx.doi. org/10.1099/vir.0.82577-0.

Ramasamy, R., Surendran, S. N., Jude, P. J., Dharshini, S., \& Vinobaba, M. (2011). Larval development of Aedes aegypti and Aedes albopictus in peri-urban brackish water and its implications for transmission of arboviral diseases. PLoS Neglected Tropical Diseases, 5(11), e1369. http://dx.doi.org/10.1371/journal.pntd.0001369. PMid:22132243.

Reeves, W. K. (2004). Oviposition by Aedes aegypti (Diptera: Culicidae) in relation to conspecific larvae infected with internal symbiotes. Journal of Vector Ecology, 29(1), 159-163. PMid:15266753.

Rubel, F., \& Kottek, M. (2010). Observed and projected climate shifts 1901-2100 depicted by world maps of the Köppen-Geiger climate classification. Meteorologische Zeitschrift (Berlin), 19(2), 135-141. http://dx.doi. org/10.1127/0941-2948/2010/0430.

Salazar, M. I., Richardson, J. H., Sánchez-Vargas, I., Olson, K. E., \& Beaty, B. J. (2007). Dengue virus type 2: replication and tropisms in orally infected Aedes aegypti mosquitoes. BMC Microbiology, 7, 9. http://dx.doi. org/10.1186/1471-2180-7-9. PMid:17263893.

Sánchez-Vargas, I., Harrington, L. C., Doty, J. B., Black 4th, W. C., \& Olson, K. E. (2018). Demonstration of eficiente vertical and venereal transmission of dengue virus type- 2 in a genetically diverse laboratory strain of Aedes aegypti. PLoS Neglected Tropical Diseases, 12(8), e0006754. http://dx.doi.org/10.1371/journal.pntd.0006754. PMid:30169505.

Schwartz, E., Weld, L. H., Wilder-Smith, A., von Sonnenburg, F., Keystone, J. S., Kain, K. C., Torresi, J., \& Freedman, D. O., \& GeoSentinel Surveillance Network (2008). Seasonality, annual trends, and characteristics of dengue among ill returned travelers, 1997-2006. Emerging Infectious Diseases, 14(7), 1081-1088. http://dx.doi.org/10.3201/ eid1407.071412. PMid:18598629.

Seferovic, M., Sánchez-San Martín, C., Tardif, S. D., Rutherford, J., Castro, E., Li, T., Hodara, V. L., Parodi, L. M., Giavedoni, L., Layne-Colon, D., Tamhankar, M., Yagi, S., Martyn, C., Reyes, K., Suter, M. A., Aagaard, K. M., Chiu, C. Y., \& Patterson, J. L. (2018). Experimental Zika virus infection in the pregnant common marmoset induces spontaneous fetal loss and neurodevelopmental abnormalities. Scientific Reports, 8(1), 1-15. http:// dx.doi.org/10.1038/s41598-018-25205-1.

Streit, J. A., Yang, M., Cavanaugh, J. E., \& Polgreen, P. M. (2011). Upward trend in dengue incidence among hospitalized patients, United States. Emerging Infectious Diseases, 17(5), 914-916. http://dx.doi.org/10.3201/eid1705.101023.

Terzian, A. C. B., Zini, N., Sacchetto, L., Rocha, R. F., Parra, M. C. P., Del Sarto, J. L., Dias, A. C. F., Coutinho, F., Rayra, J., da Silva, R. A., Costa, V. V., Fernandes, N. C. C. A., Réssio, R., Díaz-Delgado, J., Guerra, J., Cunha, M. S., CatãoDias, J. L., Bittar, C., Reis, A. F. N., Santos, I. N. P. D., Ferreira, A. C. M., Cruz, L. E. A. A., Rahal, P., Ullmann, L., Malossi, C., Araújo Junior, J. P., Widen, S., de Rezende, I. M., Mello, É., Pacca, C. C., Kroon, E. G., Trindade, G., Drumond, B., Chiaravalloti-Neto, F., Vasilakis, N., Teixeira, M. M., \& Nogueira, M. L. (2018). Evidence of natural Zika virus infection in neotropical non-human primates in Brazil. Scientific Reports, 8(1), 16034. http://dx.doi. org/10.1038/s41598-018-34423-6. PMid:30375482.

Thavara, U., Tawatsin, A., \& Nagao, Y. (2014). Simulations to compare efficacies of tetravalent dengue vaccines and mosquito vector control. Epidemiology and Infection, 142(6), 1245-1258. http://dx.doi.org/10.1017/ S0950268813001866. PMid:23925059.

Thenmozhi, V., Kabilan, L., Samuel, P. P., \& Dash, A. P. (2005). Short Communication: detection of dengue virus antigens in desiccated mosquitoes: an improved tool for surveillance. Tropical medicine \& international health: TM \& IH, 1O(2), 187-189. http://dx.doi.org/10.1111/j.1365-3156.2004.01360.x. PMid:15679562.

Urdaneta, L., Herrera, F., Pernalete, M., Zoghbi, N., Rubio-Palis, Y., Barrios, R., Rivero, J., Comach, G., Jiménez, M., \& Salcedo, M. (2005). Detection of dengue viruses in field-caught Aedes aegypti (Diptera: Culicidae) in Maracay, Aragua state, Venezuela by type-specific polymerase chain reaction. Infection, Genetics and Evolution, 5(2), 177-184. http://dx.doi.org/10.1016j.meegid.2004.09.004.

Vanchiere, J. A., Ruiz, J. C., Brady, A. G., Kuehl, T. J., Williams, L. E., Baze, W. B., Wilkerson, G. K., Nehete, P. N., McClure, G. B., Rogers, D. L., Rossi, S. L., Azar, S. R., Roundy, C. M., Weaver, S. C., Vasilakis, N., Simmons, J. H., \& Abee, C. R. (2018). Experimental Zika Virus Infection of Neotropical Primates. The American Journal of Tropical Medicine and Hygiene, 98(1), 173-177. PMid:29182145. 
Vasilakis, N., \& Weaver, S. C. (2008). The history and evolution of human dengue emergence. Advances in Virus Research, 72, 1-76. http://dx.doi.org/10.1016/S0065-3527(08)00401-6. PMid:19081488.

Vega-Rúa, A., Zouache, K., Girod, R., Failloux, A. B., \& Lourenço-de-Oliveira, R. (2014). High level of vector competence of Aedes aegypti and Aedes albopictus from ten American countries as a crucial factor in the spread of Chikungunya virus. Journal of Virology, 88, 6294-6306. http://dx.doi.org/10.1128/JVI.00370-14.

Volk, S. M., Chen, R., Tsetsarkin, K. A., Adams, A. P., Garcia, T. I., Sall, A. A., Nasar, F., Schuh, A. J., Holmes, E. C., Higgs, S., Maharaj, P. D., Brault, A. C., \& Weaver, S. C. (2010). Genome-scale phylogenetic analyses of chikungunya virus reveal independent emergences of recent epidemics and various evolutionary rates. Journal of Virology, 84(13), 6497-6504. http://dx.doi.org/10.1128/JVI.01603-09. PMid:20410280.

Wang, E., Ni, H., Xu, R., Barrett, A. D., Watowich, S. J., Gubler, D. J., \& Weaver, S. C. (2000). Evolutionary relationships of endemic/epidemic and sylvatic dengue viruses. Journal of Virology, 74, 3227-3234. http://dx.doi.org/10.1128/ jvi.74.7.3227-3234.2000.

Weaver, S. C., \& Reisen, W. K. (2010). Present and future arbovirus threats. Antiviral Research, 85(2), 328-345. http://dx.doi.org/10.1016/j.antiviral.2009.10.008. PMid:19857523.

World Health Organization - WHO. (1996). Chemical methods for the control of vectors and pests of public health importance. WHO. http://apps.who.int/iris/bitstream/10665/63504/1/WHO_CTD_WHOPES_97.2.pdf

World Health Organization - WHO. (2012). Global Health Atlas. WHO. http://apps.who.int/globalatlas/

World Health Organization - WHO. (2017). Integrating neglected tropical diseases in global health and development. Fourth WHO report on neglected tropical diseases. WHO. http://www.who.int/neglected_diseases/ resources/9789241565448/en/

World Health Organization - WHO. (2020).Arbovirosis emergentesy reemergentes transmitidas por Aedes en la Región de las Américas: implicaciones en materia de políticas de salud. WHO. https://iris.paho.org/handle/10665.2/50939

Zambrano, L. I., Sierra, M., Lara, B., Rodríguez-Núñez, I., Medina, M. T., Lozada-Riascos, C. O., \& Rodríguez-Morales, A. J. (2017). Estimating and mapping the incidence of dengue and chikungunya in Honduras during 2015 using Geographic Information Systems (GIS). Journal of Infection and Public Health, 10(4), 446-456. http:/l dx.doi.org/10.1016/j.jiph.2016.08.003. PMid:27562685.

Zara, A. L. S. A, Santos, S.M., Fernandes-Oliveira, E. S., Carvalho, R. G, \& Coelho, G. E. (2016). Aedes aegypti control strategies: a review. Epidemiologia e Serviços de Saúde, 25(2), 391-404. http://dx.doi.org/10.5123/ S1679-49742016000200017.

Zhang, W., Heil, M., Kuhn, R. J., \& Baker, T. S. (2010). Heparin binding sites on Ross River virus revealed by electron cryo-microscopy. Virology, 332(2), 511-518. http://dx.doi.org/10.1016/j.virol.2004.11.043. PMid:15680416. 